\title{
Doppler radar observation, CG lightning activity and aerial survey of a multiple downburst in southern Germany on 23 March 2001
}

\author{
Nikolai Dotzek $^{\mathrm{a}, *}$, Peter Lang ${ }^{\mathrm{b}}$, Martin Hagen ${ }^{\mathrm{a}}$, Thorsten Fehr ${ }^{\mathrm{a}, 1}$, Werner Hellmiss ${ }^{\mathrm{c}}$ \\ ${ }^{a}$ DLR-Institut für Physik der Atmosphäre, Oberpfaffenhofen, 82234 Wessling, Germany \\ ${ }^{\mathrm{b}}$ DWD-Meteorologisches Observatorium Hohenpeißenberg, Albin-Schwaiger-Weg 10, 82383 Hohenpeißenberg, Germany \\ c DWD-Regionales Gutachtenbüro München, Helene-Weber-Allee 21, 80637 München, Germany
}

Accepted 17 August 2005

\begin{abstract}
Two downburst events from one thunderstorm are investigated, which occurred on 23 March 2001, in Germany's climatologic annual minimum of downburst activity. Observations by two Doppler radars are combined with hail reports, ground lightning detection and an aerial survey conducted after the event. The downburst-producing storm had formed at a synoptic convergence line within the warm sector of a cyclone. It had a remarkably high propagation speed of up to $31 \mathrm{~m} \mathrm{~s}^{-1}$ corresponding to the midtropospheric flow. Thus, by superposition with the storm motion, even two weak downbursts were sufficient to cause the observed damage of F1 and F2 intensity, respectively. While in its late stages, the storm was dynamically characterized by lower- and midtropospheric divergence; at about the time of the first downburst, a mesocyclonic vortex signature was verified. Aside from midtropospheric dry air entrainment, a thermodynamic explanation for the triggering of the two downbursts by melting of small hail according to recent findings by Atlas et al. [Atlas, D., Ulbrich, C.W., Williams, C.R., 2004. Physical origin of a wet microburst: observations and theory. J. Atmos. Sci. 61, 1186-1196] appears probable. Despite the lack of warnings to the public, the storm's potential for hail and strong straight-line winds was detected by the German weather service radar software CONRAD more than a half hour before the downbursts occurred.
\end{abstract}

(C) 2006 Elsevier B.V. All rights reserved.

Keywords: Thunderstorm; Downburst; Radar; Lightning; Aerial survey

\section{Introduction}

Downbursts as a special class of straight-line wind events present a considerable hazard not only to property and human lives, but in particular to aircraft during take-off and landing (cf. Fujita, 1981, 1985;

\footnotetext{
* Corresponding author. Tel.: +49 815328 1845; fax: +49 815328 1841 .

E-mail address: nikolai.dotzek@dlr.de (N. Dotzek).

URL: http://essl.org/people/dotzek/ (N. Dotzek).

${ }^{1}$ Present affiliation: ESA-ESRIN, Via Galileo Galilei, Casela Postale 64, 00044 Frascati, Italy.
}

Doswell, 2001). On 23 March 2001, two downbursts occurred in close vicinity of special airport Oberpfaffenhofen southwest of Munich. The ground track of the fast-moving thunderstorm's high winds went right across the airport area lying between the two actual downbursts. Fortunately, no aircraft were approaching or departing at this time, and most of the damage occurring was to forests and roofs in the main downburst areas.

The German tornado climatology was recently investigated by Dotzek et al. (2000) and Dotzek (2001, 2003). In order to assess representativeness of 

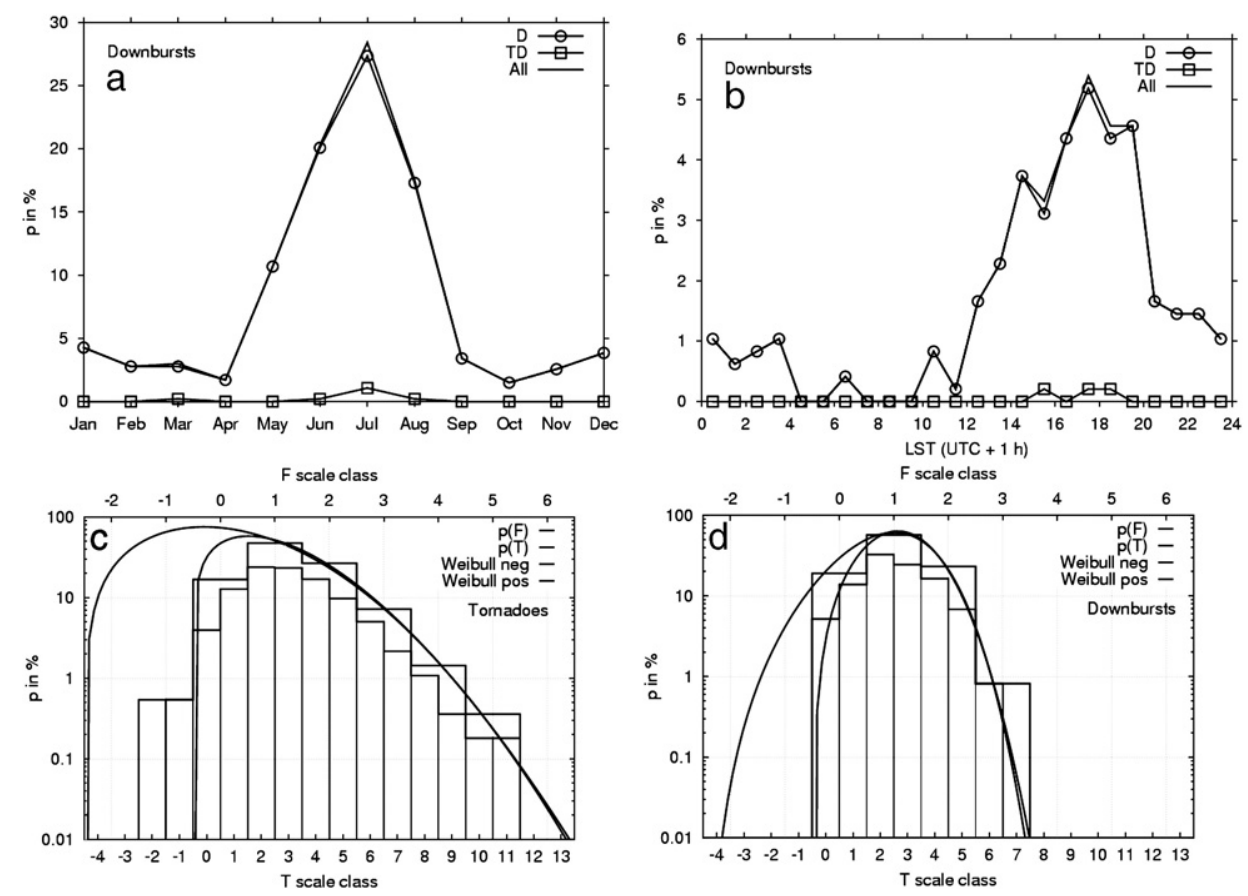

Fig. 1. Annual (a, 468 samples) and diurnal cycles (b, 195 samples) from a total of 485 downburst reports in Germany. The curves labeled TD involve a few cases in which distinction between downburst and tornado was unclear. Comparison between tornado and downburst intensity distributions with F- and T-scale is shown by the step-functions in (c, 557 samples of 863) and (d, 368 samples), respectively. Weibull fits according to Dotzek et al. (2003) and Feuerstein et al. (2005) are also given. Data from TorDACH archive version 1.4 (spring 2004).

the present downburst case, it is instructive here to look at the German downburst climatology first. This will show if the 23 March case was a typical event or more exceptional. Note that downbursts in Germany are almost exclusively wet downburst events. Fig. 1 reviews fundamental aspects of Germany's downburst climatology based on the TorDACH data (version 1.4, as of spring 2004). The annual cycle is given in Fig. 1a. A dominant July maximum of downburst activity is obvious. Generally, from May to August, the chances for downbursts to occur are significant and there is a weak secondary maximum in mid-winter. The downbursts considered in this paper are exceptional, as March is among the months with the lowest percentage of downburst reports.

Fig. $1 \mathrm{~b}$ gives the diurnal cycle. Peak activity is limited to the afternoon and evening hours, with some further activity during the night. On 23 March, the downbursts occurred after approximately 1605 LST (1505 UTC), so with this respect, the present case is quite typical. Fig. 1c, $\mathrm{d}$ compare the intensity distributions for tornadoes $(\mathrm{c}, \mathrm{cf}$. Dotzek et al., 2003; Feuerstein et al., 2005) and downbursts (d) as a function of both Fujita's F-scale (Fujita, 1971; Fujita and Pearson, 1973) and TORRO's T-scale (Meaden, 1976). While tornado reports are present up to F5 intensity on the F-scale, the downbursts in Fig. 1d are limited to the range up to F3, consistent with findings from the USA (Fujita, 1981, 1985). Cases of F1 and F2 intensity make up the majority of reports. Thus, also concerning the intensity, the 23 March downbursts are not exceptional. It is the unusual time of year that makes this case most interesting, also for comparison to more typical summer cases presented by Dotzek et al. (2001), Dotzek and Friedrich (2003, submitted for publication) and Fehr et al. (2005).

The paper is organized as follows: Section 2 outlines the storm environment and some eyewitness reports on 23 March 2001. In Section 3, the available radar, lightning and hail observations as well as the outcome of the aerial damage survey are presented. Sections 4 and 5 present discussion and conclusions.

\section{Storm environment on 23 March 2001}

A low pressure center over the English Channel and two high pressure areas west and south of the Alps were the main synoptic features on that day. Fig. 2a gives a detail of the surface analysis of 23 March 1200 UTC. The main frontal system of the low is characterized by a warm sector north of the Alps, with the cold front 

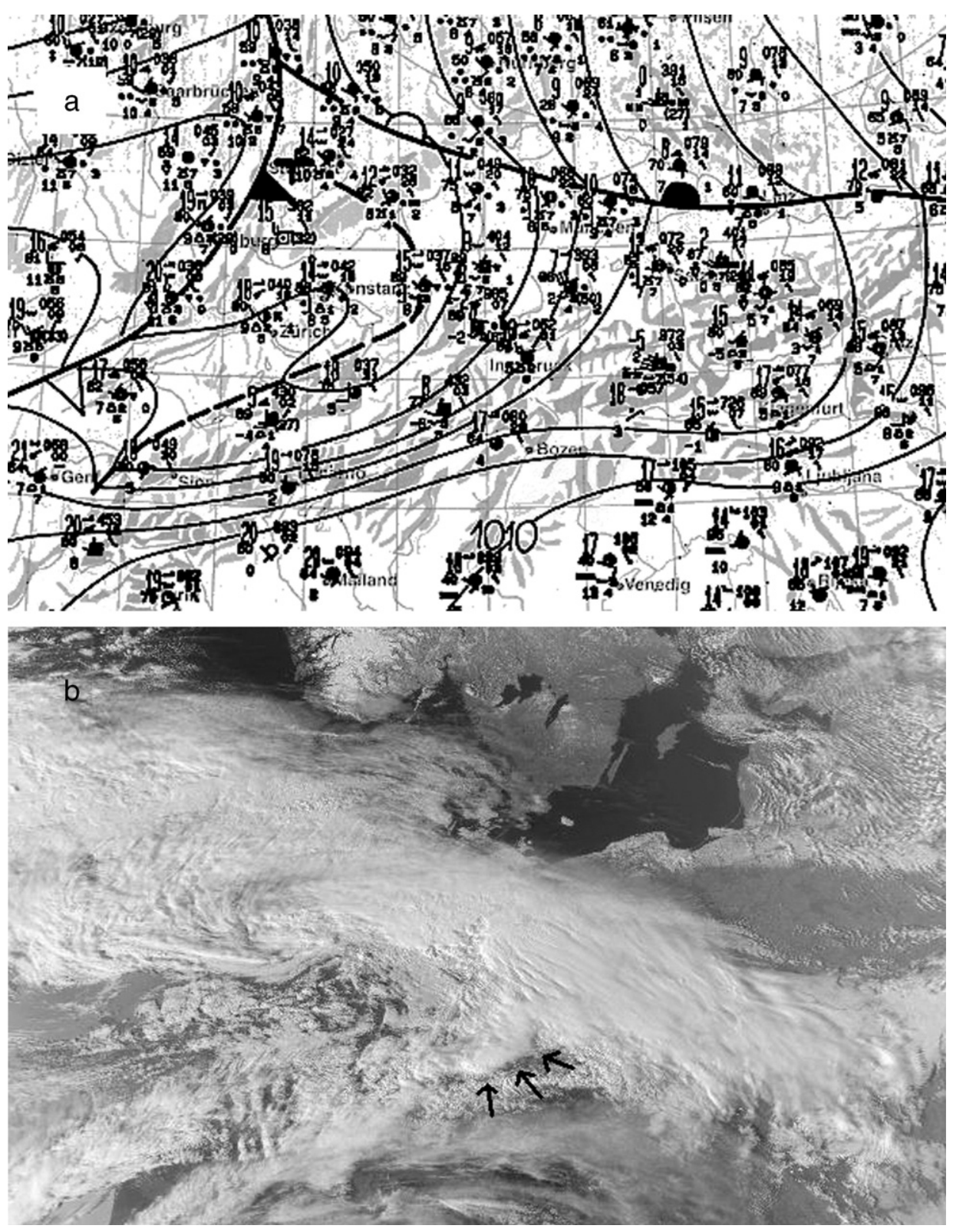

Fig. 2. Synoptic surface chart of 23 March 2001, 1200 UTC (a). Note the pronounced convergence line just north of the Alps within the southern warm sector. NOAA VIS satellite image at 1506 UTC (b), showing the line of thunderstorms (marked by three arrows) a few minutes before the first downburst occurred. Note how the line had formed nearly perpendicular to the main warm frontal cloud shield, likely corresponding to the convergence line visible in the surface chart in (a, dashed).

approximately over the Upper Rhine valley at that time. The partially elevated warm front resides over southern Germany, stretching out from about Frankfurt to the Danube valley north of Munich. The most prominent feature within the warm sector is an arched, commashaped convergence line extending from the Swabian Jura south- and southwestward along the Alps near Lake Constance.
Fig. $2 \mathrm{~b}$ shows the NOAA-POES visible satellite image of the area about $3 \mathrm{~h}$ later, at 1506 UTC shortly before the first downburst. The main cloud shield of the warm front extending from England to Austria is obvious. Just north of the Alps, and marked by three arrows, is a bow-shaped cirrus anvil from a line of thunderstorms, which have developed nearly perpendicular to the warm front. Comparison to the surface 
analysis leads to the conclusion that these storms were most likely initiated along the warm sector convergence line mentioned above. So, apparently, one necessary ingredient for thunderstorm formation (cf. Doswell et al., 1996) was present in this case: mesoscale lift.

Fig. 3 allows for a judgment on the two other necessary ingredients: low-level moisture and instability, expressed as lapse rate magnitude. Fig. 3a,b show the 1200 UTC Stuttgart and Munich soundings, respectively. They are both characteristic of the prestorm environment (Brooks et al., 1994) of this event. Fig. 3c showing the 24 March, 0000 UTC Munich sounding is representative of the post-storm air mass. Both 1200 UTC soundings show rather homogeneous air mass characteristics. Surface temperatures ranged at about $10{ }^{\circ} \mathrm{C}$, and the cold-point tropopause on this day was located near the $200 \mathrm{hPa}$ level below $11 \mathrm{~km}$ ASL. While the air between 800 and $500 \mathrm{hPa}$ was rather moist, reaching saturation near and slightly below the $0^{\circ} \mathrm{C}$ level (at about $2 \mathrm{~km} \mathrm{ASL}$ ), the upper troposphere was relatively dry. Thus, low-level moisture was present as an ingredient for deep moist convection, and the drier air aloft further served as a component towards instability. However, the temperature lapse rates alone were not giving evidence for potentially unstable atmospheric stratification. They correspond much more to moist-adiabats than to dry adiabatic lapse rates. Consequently, the convective available potential energy (CAPE) as well as the convective inhibition (CIN) were both diagnosed to be zero. Here, CAPE was computed by lifting an average parcel from the lowest $500 \mathrm{~m}$ of the atmosphere. So the last ingredient, instability (either defined by local temperature lapse rate or by the bulk quantity CAPE) is not apparent from the soundings in Fig. 3a,b.

However, analysis of the vertical profiles of equivalent potential temperature $\theta_{\mathrm{e}}$ uncovers the presence of several layers with an upward decline in $\theta_{\mathrm{e}}$ : Aside from the lower boundary layer, both 1200 UTC soundings from Stuttgart and Munich show negative $\theta_{\mathrm{e}}$-gradients between roughly 750 and $600 \mathrm{hPa}$, and Stuttgart also from 540 to $450 \mathrm{hPa}$. Obviously, there is instability present in the soundings, even though the bulk quantity CAPE fails to reveal it, but only the $\theta_{\mathrm{e}}$ lapse rates do. And besides, what is apparent and also remarkable is the strong wind shear present in both soundings: Winds veer with height from weak southeasterly surface winds to strong westerly winds at about $3 \mathrm{~km} \mathrm{ASL}$, and further to a maximum of west-northwesterly winds at roughly $7 \mathrm{~km}$ ASL. This is a wind profile with a high potential of storm organization into supercells, but as CAPE was
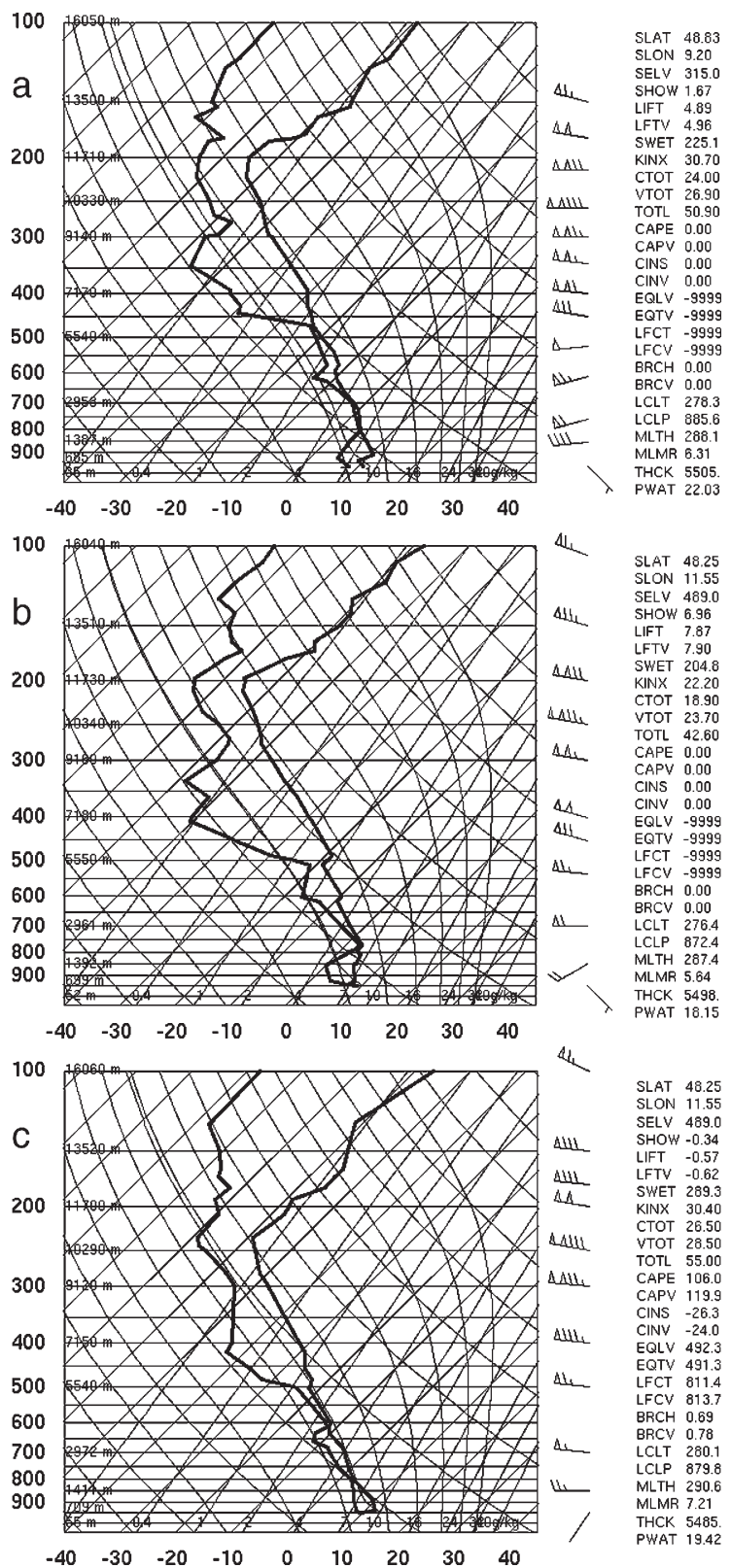

Fig. 3. Stuttgart (a) and Munich (b) soundings of 1200 UTC (a). Panel (c) gives the 24 March 0000 UTC Munich sounding. While the 1200 UTC soundings show neither CAPE nor CIN based on the standard University of Wyoming computation, both directional and velocity shear are remarkable.

diagnosed to be zero, all thunderstorm parameters involving CAPE did not yield meaningful values. Also other frequently used parameters like the Lifted Index (LI) did not point to instability. This indicates that sounding-derived forecast parameters alone can provide misleading results and should not be used on a standalone basis (cf. Doswell et al., 1996). And finally, for 
straight-line wind events driven by negative buoyancy as the present squall line-embedded downburst case, a measure of the according available potential energy is much more relevant than the updraft-related CAPE. Such a bulk measure is the downdraft-CAPE or negative-APE (DCAPE or NAPE, cf. Doswell, 1993). Unfortunately, DCAPE is not routinely computed from operational soundings, at least in Europe.

From the Stuttgart and Munich proximity soundings at 1200 UTC, thunderstorms appeared not very likely. Yet, in the region of the convergence line, there must have been processes, which lead to at least some amount of potential instability, and in turn CAPE, which was released by the mesoscale lift at the convergence line. Low-level warm air advection in a "conveyor belt" (e. g. Cotton and Anthes, 1989) ahead of the approaching cold front is a candidate process for the generation of CAPE. The sounding parameters in Fig. 3a,b give a low lifted condensation level (LCL) height of $880 \mathrm{hPa}$ (approximately $1 \mathrm{~km} \mathrm{AGL)} \mathrm{and,}$ taking into account the temperatures and moisture on 23 March, we may argue that any level of free convection (LFC) would not be very much above the LCL. Having thunderstorms develop in an environment of strong low-level wind shear and low cloud base is a potentially dangerous setup (cf. Brooks et al., 2003), even if the sounding-derived cold-point tropopause would only allow cloud tops below $10 \mathrm{~km}$ ASL.

When the line of thunderstorms was approaching the Munich area at about 1505 UTC (cf. Fig. 2b), the first author noted their very low and unusually dark, textured cloud base. Their appearance was so uncommon for the early time in the year that it was decided to take radar measurements with the C-band polarization diversity radar (POLDIRAD, cf. www.pa.op.dlr.de/poldirad/) at DLR, even though no severe thunderstorms had been forecast earlier that day. During the radar start-up process, the first F1 downburst occurred $12 \mathrm{~km}$ west of the POLDIRAD site, near the village Türkenfeld. Thereafter, when the radar was performing the first $1^{\circ}$ base-level PPI scan at 1515 UTC, it was hit by very strong and gusty winds of up to $25 \mathrm{~m} \mathrm{~s}^{-1}$ sustained speed. Due to the high wind load, the radar was forced to an emergency stop after the first PPI and only came alive again after almost $30 \mathrm{~min}$.

Shortly after POLDIRAD was hit by the storm's straight-line winds, one of the authors of this paper (W. H.) was out in the forest of the Forstenrieder Park area at the southwestern fringe of Munich and about $12 \mathrm{~km}$ east of the POLDIRAD radar position. He saw the storms approaching and, when the winds increased and small hail with sizes below $1 \mathrm{~cm}$ set in, he looked for shelter under a large old spruce tree. After a while (at about 1520 UTC), he decided to leave the forest and run for his car, as wind and hail continued to intensify. Soon after he had left, the storm hit the area with the second downburst, now of F2 intensity — also snapping the large spruce tree which had looked like safe shelter shortly before. So, by coincidence, some of the authors had the chance to experience the storm from very close range.

In Fig. 3c, the Munich sounding of 24 March, 0000 UTC gives an impression of the post-storm air mass, after the downburst-producing squall line and subsequent thunderstorms had passed. The wind shear is still significant, but the directional shear has decreased, with surface winds now from the southwest. The dryness of the upper troposphere has decreased, probably due to moistening by the thunderstorms themselves. Now also some small amounts of CAPE and CIN are diagnosed: $\mathrm{CAPE}=120 \mathrm{~J} \mathrm{~kg}^{-1}, \mathrm{CIN}=-24 \mathrm{~J} \mathrm{~kg}^{-1}$. The LFC of $814 \mathrm{hPa}$ (approximately $1.5 \mathrm{~km} \mathrm{AGL}$ ) is indeed not very much higher compared to the LCL of $880 \mathrm{hPa}$, as argued above.

\section{Observations}

\subsection{Doppler radar}

In Fig. 4, we combine observations by the German weather service (DWD) C-band Doppler radar at Meteorological Observatory Hohenpeißenberg (MOHP, 1002 m ASL, cf. www.dwd.de/en/FundE/Observator/ MOHP/MOHP.htm) and by DLR's C-band polarization diversity Doppler radar POLDIRAD (603 m ASL, Schroth et al., 1988). The panels in Fig. 4 (a, c: MOHP; $\mathrm{b}, \mathrm{d}$ : POLDIRAD) are in chronological order, but following the line of presentation in the previous section, we start with a discussion of POLDIRAD observations from within the downbursts' path.

Fig. $4 \mathrm{~b}$ shows the first $1^{\circ}$ base-level plan position indicator scan of reflectivity (PPI-Z) after POLDIRAD was switched on. Apparently, at this moment (1515 UTC), the downburst-producing thunderstorm embedded into a line of convection is just north abeam the radar site. POLDIRAD's antenna, unprotected by a radome, experienced sustained wind speeds of about $25 \mathrm{~m} \mathrm{~s}^{-1}$, causing strong oscillations of the $5-\mathrm{m}$ diameter dish reflector both in azimuth and elevation due to the large exerted wind forces. The effect of oscillations in elevation can clearly be seen by several sectors without any signal in the PPI-Z. At the end of this scan, oscillations had become dangerously strong, 

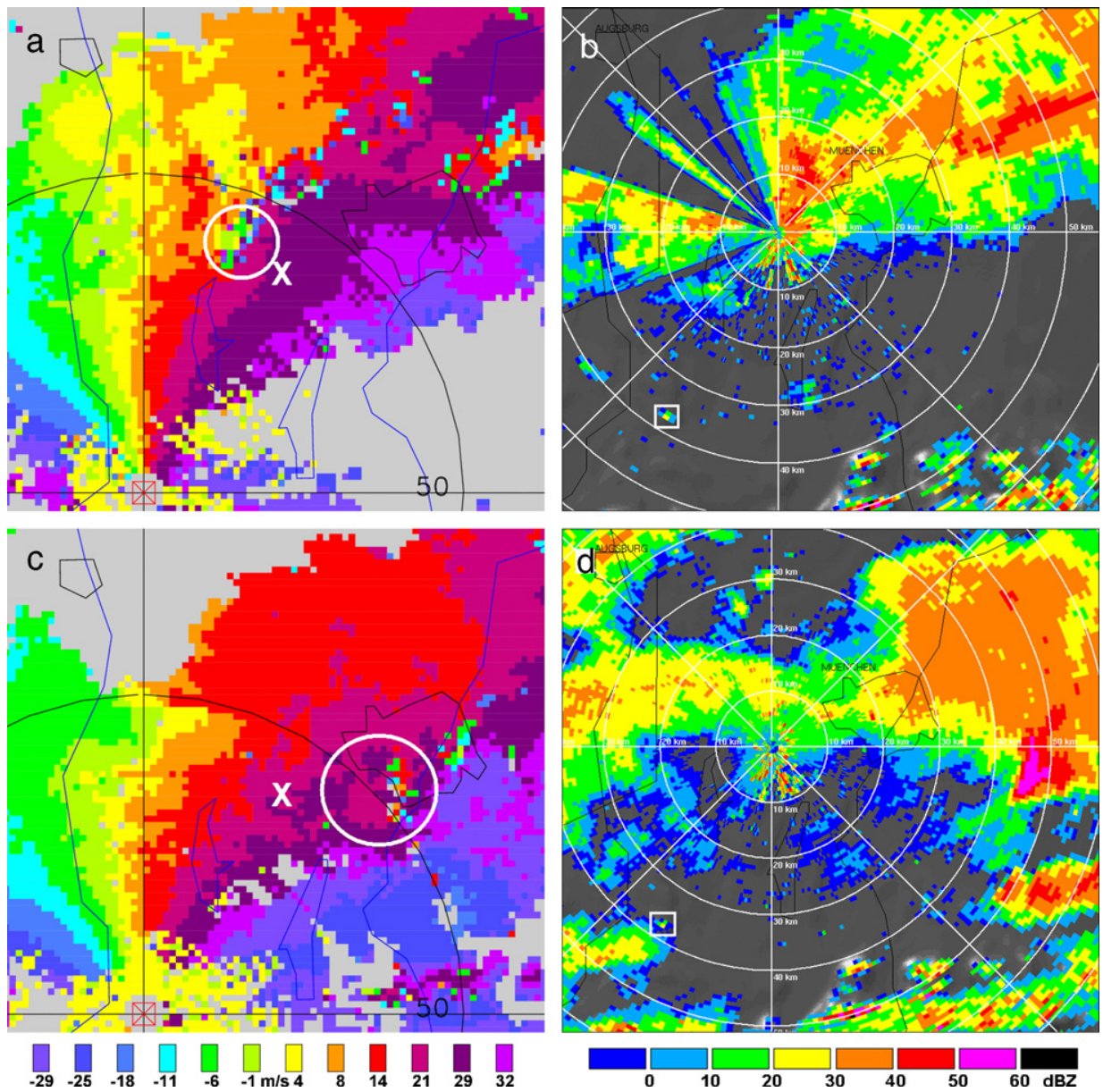

Fig. 4. MOHP 4 km ASL CAPPI-v scans, (a) 1508 UTC when the first downburst occurred and (c) 1523 UTC at the time of the second downburst. Polar coordinate system centered at MOHP radar site, POLDIRAD site is marked by an X. White circles denote downburst regions, in which the leading edge of the downdraft is seen by areas with multi-colored pixels. The two other panels are POLDIRAD $1^{\circ}$ PPI-Z scans, (b) 1515 UTC when the storm hit the radar site and (d) 1542 UTC when the storm had already moved on east for $50 \mathrm{~km}$ and still maintained a V-shaped radar echo. MOHP radar position is marked by the box symbol.

forcing the azimuth and elevation control servos into an emergency stop.

Only after almost half an hour (and after the second downburst), the radar was operational again. Fig. $4 d$ shows the base-level PPI-Z at 1542 UTC. The storm is now located at $50 \mathrm{~km}$ range about east-southeast of the POLDIRAD site at DLR. From that, a storm propagation speed of about $31 \mathrm{~m} \mathrm{~s}^{-1}$ can be diagnosed - a remarkably high value. This leads to the fact that even a weak F0 downburst from that cell would have been sufficient to cause the observed F1 and F2 wind damage by superposition of downburst and translational wind speeds from storm propagation. Note the V-shape (or Vnotch) of the storm's high reflectivity core in Figs. 4d and 5a, often accompanying severe storms (cf. Dotzek et al., 2005).

The volume scan in Fig. 5 starting at 1543 UTC revealed that the echo tops of the storm were below

Fig. 5. POLDIRAD PPI scans of reflectivity (left column) and Doppler velocity (right column): 1543 ( $1^{\circ} \mathrm{PPI}$; a, b), 1544 ( $2^{\circ} \mathrm{PPI}$; c, d), 1544 ( $3^{\circ} \mathrm{PPI}$; $\mathrm{e}, \mathrm{f}), 1545$ ( $\left.4^{\circ} \mathrm{PPI} ; \mathrm{g}, \mathrm{h}\right)$. Note that the Doppler velocities are aliased and so the corresponding key centered at $32 \mathrm{~m} \mathrm{~s}^{-1}$ was added. In panels (b) and (d), the reddish colors at the northern forward flank of the cell are "folded back" and indicative of outbound winds of only about $9 \mathrm{~m} \mathrm{~s}$. divergence signature at the southern tip of the cell is marked by the circle and, in panel (a), likely rear-flank downdraft gust fronts of the V-shaped cell are marked by the dashed lines. 

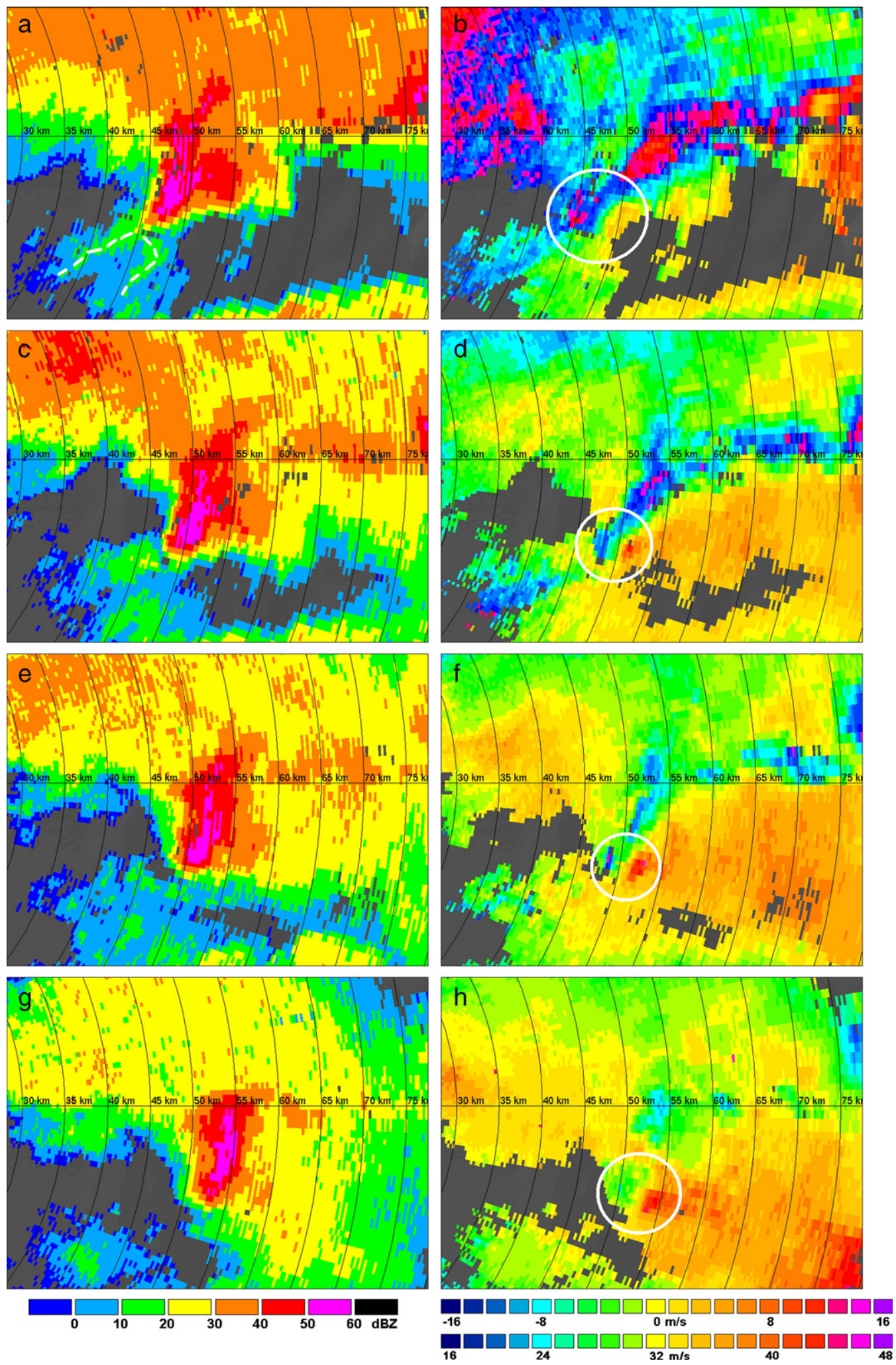
$9 \mathrm{~km}$ AGL. This is consistent with the apparent negligible CAPE and the cold-point tropopause height of about $10 \mathrm{~km}$ ASL. Near the southern tip of the Vshaped thunderstorm, the (aliased) Doppler velocity field in Fig. 5 shows a strong divergence dipole signature in the $1^{\circ}(\mathrm{b}), 2^{\circ}(\mathrm{d}), 3^{\circ}(\mathrm{f})$ and $4^{\circ}(\mathrm{h})$ PPI-v, corresponding to heights of $1.6,2.5,3.4$ and $4.4 \mathrm{~km}$ ASL, respectively. This elevated, deep divergence confirms that the 23 March cell was already decaying at this time. No convincing signs of mesocyclonic rotation are found at this stage, from which also no more damage reports are available. Note that the central value of the aliased Doppler velocity scale in Fig. 5 $\left(32 \mathrm{~m} \mathrm{~s}^{-1}\right)$ corresponds well to the storm propagation (ca. $31 \mathrm{~m} \mathrm{~s}^{-1}$ ) in this case. The PPI-Z in Fig. 5a shows another interesting feature: two arched bands of moderate reflectivity between 10 and $20 \mathrm{dBZ}$ (marked by the white dashed lines). These may be signs for the presence of rear-flank downdrafts with this cell.

Fortunately, DWD's MOHP radar provided more information from the times of the actual downbursts. At 1508 UTC (Fig. 4a), the radar detected a mesocyclonic vortex signature (MVS) in the storm at the 4km ASL level constant altitude PPI of Doppler velocity (CAPPI-v). Derived from a dual-PRF scan and dealiasing procedure, the MVS dipole had peak radial velocities of about $25 \mathrm{~m} \mathrm{~s}^{-1}$ over a distance of $4.5 \mathrm{~km}$, corresponding to a vorticity of $0.01 \mathrm{~s}^{-1}$. The reflectivity pattern of the storm (not shown) already displays a Vshape at 1509 UTC, also seen later on in Figs. 4d and 5 a. However, the mesocyclone was apparently not very persistent. At $1523 \mathrm{UTC}$, the V-shape of the cell was still apparent, but the CAPPI-v in Fig. 5c gives no clear indication of an MVS or a purely convergent or divergent Doppler velocity dipole. Taking into account the divergence signature in the POLDIRAD Doppler velocity PPI-v at 1543 UTC, and the fact that the angle between MOHP and POLDIRAD radar lines of sight for this storm is about $60^{\circ}$, it is clear that while POLDIRAD was almost straight upstream of the storm, MOHP radar was geometrically in a less suitable position to detect the in-cloud divergence.

However, DWD's tracking and warning software CONRAD (Lang, 2001) applied to the MOHP Doppler radar led to good results identifying the storm's severity potential in the time interval 1430 to 1530 UTC. Fig. $6 \mathrm{a}$ gives the ground track of the cell every $3 \mathrm{~min}$, supplemented by hail and wind gust warning indicators. The downburst-producing cell had entered the area of Fig. 6a from the west between the cities of Augsburg and Landsberg and then rapidly propagated eastsoutheasterly between lake Starnberg and the southern parts of Munich. The very high translational speed of that particular storm is obvious, and higher than for instance the propagation of the cell visible north of Munich. Such variability in speed of even nearby storms certainly makes a forecaster's job no easier and hampers timely warnings of the public.

Fig. $6 \mathrm{~b}$ gives the location of the damage zones and an estimation of the peak wind track as derived from the aerial survey described in more detail below. Note that the damage swath is located south of the CONRAD-derived cell track in Fig. 6a. With the conceptual model of a supercell storm in mind, this observation would fit the notion that the downbursts originated from the storm's rear-flank downdraft. However, as the radar data showed, the storm was not a classic supercell and hence the conclusion of a true supercell rear-flank downdraft (RFD) causing the damage is not fully compelling. Instead, the general rear-flank downward motion along the squall line may have been locally intensified by the embedded stronger thunderstorm. In any case, taking into account that the two main damage zones are close to several villages and the second downburst crossed one major highway, it is very fortunate that no one was injured.

\subsection{Hail reports and $C G$ lightning detection}

Hail was a widespread phenomenon with the downburst-producing storm. CONRAD (Fig. 6a) gave hail indicators with the cell for the full time span from 1430 to 1530 UTC. Yet apparently, no large hail with sizes beyond $2 \mathrm{~cm}$ diameter was reported. Aside from hail reports from some of Munich's western quarters and from Forstenrieder Park southwest of the city, additional reliable reports are available from five stations of DWD's network of volunteer weather observers (Klimastationen) who also note significant weather in their logs.

The five stations lie in a latitude band between 48.02 to $48.27^{\circ} \mathrm{N}$ and from 10.78 to $11.96^{\circ} \mathrm{E}$ longitude. They are marked by large box symbols in Fig. 7 . Following the storm's mainly west-east propagation, the stations are in the following order: BobingenStraßberg, Krailing, Hohenbrunn, Oberpframmern and Ebersberg. Bobingen reported small hail from 1440 to 1447 UTC and an intense rain shower from 1440 to 1450 UTC. Krailing had small hail from 1520 to 1521 UTC. Hohenbrunn reported thunder between 1515 and 1540 UTC, hail of small-to-medium intensity between 1520 and 1530 UTC, followed by light rain. Later on, Oberpframmern reported hail from 1540 to 1545 UTC and an intense rain shower from 1530 to 

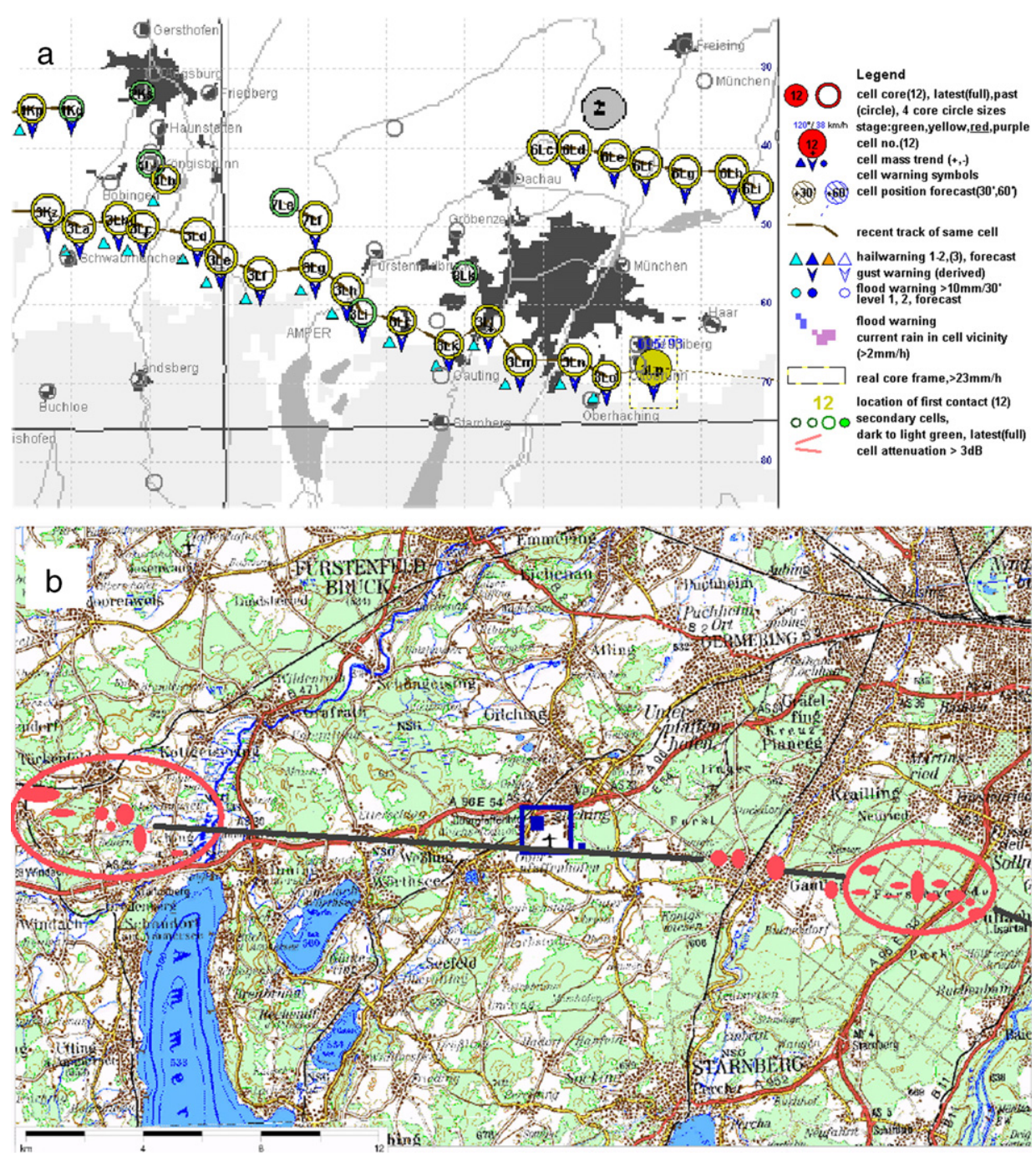

Fig. 6. CONRAD cell tracking (circles) with hail and gust indicators between 1430 and 1530 UTC, every 3 min (a). Mean cell speed above $25 \mathrm{~m} \mathrm{~s}^{-1}$, sometimes up to $31 \mathrm{~m} \mathrm{~s}^{-1}$. The origin of the coordinate system is at $48^{\circ} \mathrm{N}, 11^{\circ} \mathrm{E}$. In (b), a map of the patchy damage zones as derived from the aerial survey is given. Each filled ellipse corresponds to a damage area; the open ellipses surround the areas with highest damage. The open square between the westerly damage area near Türkenfeld and the easterly one in Forstenrieder Park shows the Oberpfaffenhofen special airport area. The small filled square within gives POLDIRAD radar site at DLR.

1545 UTC. Finally, Ebersberg had small hail from 1535 to 1540 UTC and an intense rain shower from 1530 to 1545 UTC. In summary, the storm was not characterized by large hail, which gives evidence for a probable thermodynamic mechanism of downburst triggering by melting of small hailstones inside the cloud (Atlas et al., 2004). Further, none of the DWD volunteer observers noted extreme wind speeds, substantiating the small horizontal dimension of the peak wind area.

Lightning detection data from the BLIDS network operated by Siemens in Germany and Switzerland are also available for this case. This system mainly detects ground flashes (CG) and only to a small extent cloud lightning (IC). The system consists of IMPACT sensors comparable to those applied in the National Lightning Detection Network (NLDN) in the USA (Cummins et al., 1998). Fig. 7 gives a map of the detected flashes from 1345 to 1615 UTC. It is seen that most of the 475 flashes are located northward of the cell and its damage track shown in Fig. 6. The majority of flashes (344) were of negative polarity, and no significant trends in the percentage of positive flashes before or during the downburst were apparent. Note that many of the 


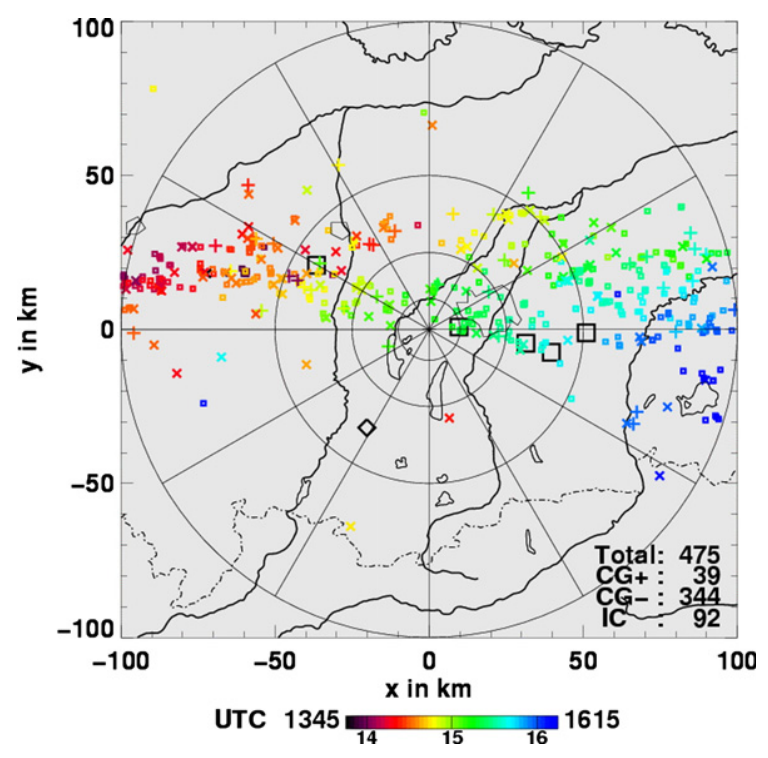

Fig. 7. CG lightning activity measured by the BLIDS network between 1345 and 1615 UTC (475 flashes, $+=\mathrm{CG}^{+}$, box $=\mathrm{CG}^{-}$, $x=I C$ ) with color of flash symbols indicating time. The origin of the coordinate system is POLDIRAD radar site at DLR, location of MOHP radar site is given by the diamond symbol, and the five DWD volunteer weather stations reporting hail on 23 March are denoted by large box symbols.

92 IC flashes were located far south of the line and may have been spurious signals, e.g., caused by ionospheric reflections of $\mathrm{CG}$ flash radiation from the squall line (cf. Dotzek et al., 2005).

\subsection{Aerial survey}

Figs. 8 and 9 show typical damage as observed in the aerial survey of the damage track a few days after the downbursts. The survey was performed with one of DLR's touring motor gliders which allows for detailed inspection of even small areas due to its high maneuverability and wide range of cruise speeds from about 25 to $55 \mathrm{~m} \mathrm{~s}^{-1}$. Post-event aerial surveys had already been suggested by Letzmann (1939) in his guidelines to assess tornado damage in forests (cf. Peterson, 1992a,b) resulting from his ground-breaking work on near-surface wind fields in tornadoes (Letzmann, 1923; cf. Dotzek et al., 2000). However, only later on, e.g., Fujita $(1981,1985)$ has thoroughly demonstrated the benefit of aerial surveys for wind damage assessment.

Fig. 8 depicts F1 damage from the first downburst near Türkenfeld. Panel (a) shows uprooted poplar trees on rather wet soil. Here on the open field, we probably get the most reliable impression of the undisturbed wind field. The swath of uprooted trees is rather wide and the trees' fall pattern is quite straight or even slightly divergent. Letzmann $(1923,1939)$ had noted that weak tornadoes from fast-moving parent thunderstorms also have the capability of producing nearly straight-line damage patterns. However, in this case, we have a wide swath in which some trees remained here and there. From a tornado, we would expect a more homogeneous damage pattern over the swath width. Panels (b) and (c) show individual damage spots, or "nests", near the edges of mature spruce stands. Again, the trees' fall pattern gives no clear evidence of vortical winds and rather shows weakly divergent fall directions of the spruce trunks. As further outlined by Hubrig (2004) in his detailed assessment of forest damage by downbursts and tornadoes, trees at forest edges are more stable than those amidst the forest. So the uprooted and snapped spruce trees in these panels (b) and (c) point to damage in the upper F1 range (T3). This estimate is also consistent with the partial roof damage observed in the survey.

Fig. 9 documents F2 (T4) damage from the second downburst in Forstenrieder Park. The main evidence of F2 intensity, several snapped mature bare oak trees, does not show well on the aerial photos and therefore had to be omitted. Similar arguments hold for some uprooted or snapped old solitary spruce trees. But another proof of F2 intensity is the larger horizontal extent of the damage nests (Hubrig, 2004) in the spruce forest of Forstenrieder Park as seen in panels (a)-(c), compared to the damage near Türkenfeld. Damage occurred at forest edges (a), but also within the forest in elongated (b) or broadened damage areas (c). In none of the damage nests, clear signs of rotation were found, but instead they again showed more straight-line or divergent patterns, similar to those of the first, weaker downburst.

\section{Discussion}

Combination of the different remote sensing and in situ observations like the aerial survey proved to be very fruitful in analyzing this case. This is in close line of what Letzmann (1939) had anticipated and was carried over to modern applications by Fujita later on (cf. Fujita, 1981, 1985). In Europe, post-storm aerial surveys have rarely been conducted (e.g., Dessens and Blin, 1988). From our first experience with an aerial survey in combination with Doppler radar, lightning and hail report data, we can recommend that aerial surveys should be conducted whenever possible after severe 

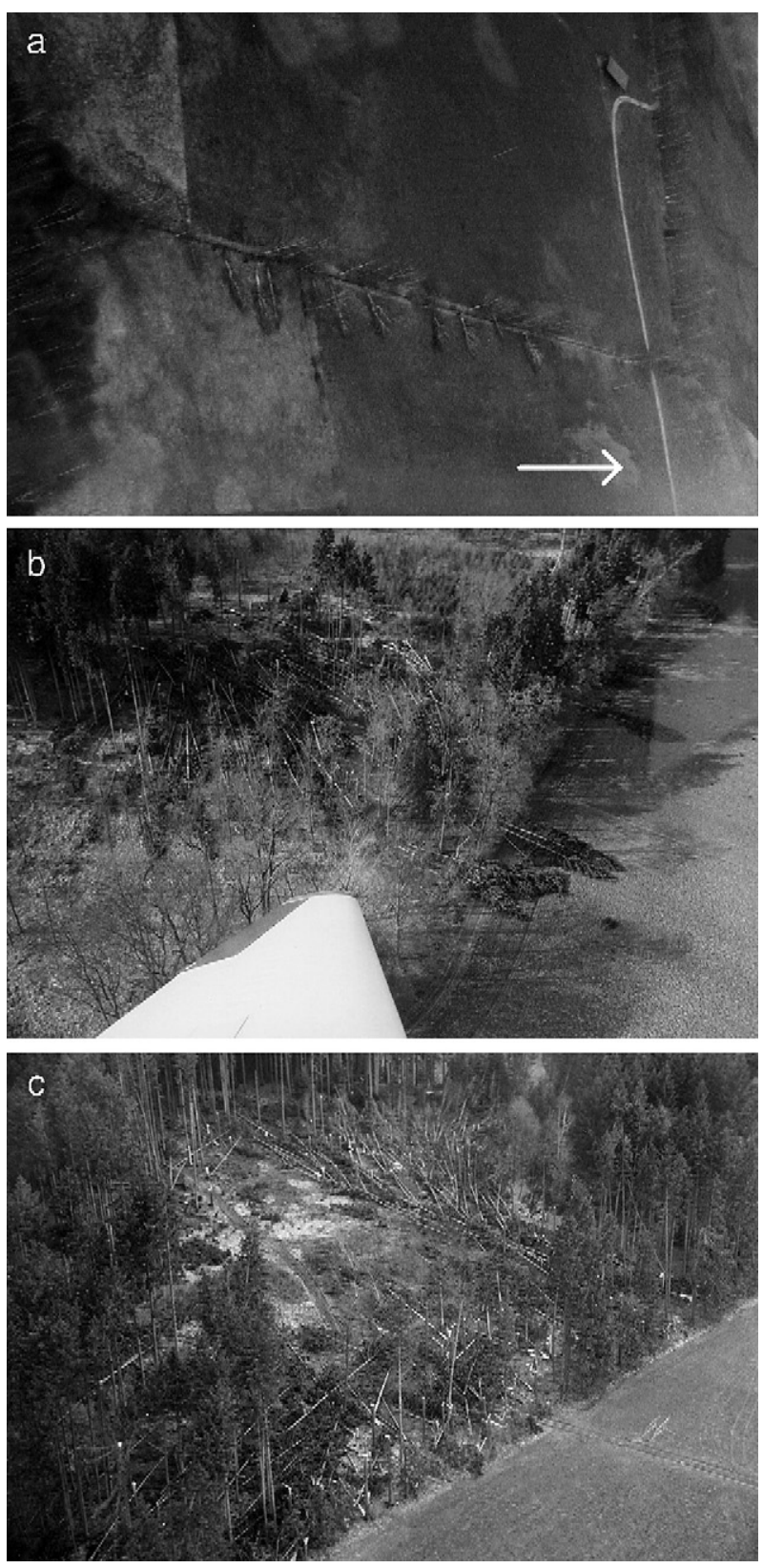

Fig. 8. Aerial views of F1 forest damage near Türkenfeld. Note that photo (a), showing downed bare poplar trees on wet soil, has been rotated clockwise by $90^{\circ}$. Top is indicated by an arrow. Panels (b) and (c) show damage nests in spruce stands.

storm events. With modern multispectral satellite imagery in meter-resolution becoming more available in the near future, also satellite "aerial" surveys might provide the chance for a larger number of such damage assessments.

From the data presented, we are of the opinion that these two storm damage areas were caused by downbursts, and not by tornadoes. Shortly after the event, there was some argument about this matter. Some eyewitnesses had reported to have seen a tornado, using the term "Windhose". This is one of the traditional German words for "tornado" (Wegener, 1917), but has often been imprecisely applied by the media and public to any kind of small-scale wind damage in recent decades. Consequently, checking back with two eyewitnesses (one from each downburst event), these could not unambiguously clarify what exactly they had seen. None of them mentioned a tornado funnel or rotating 

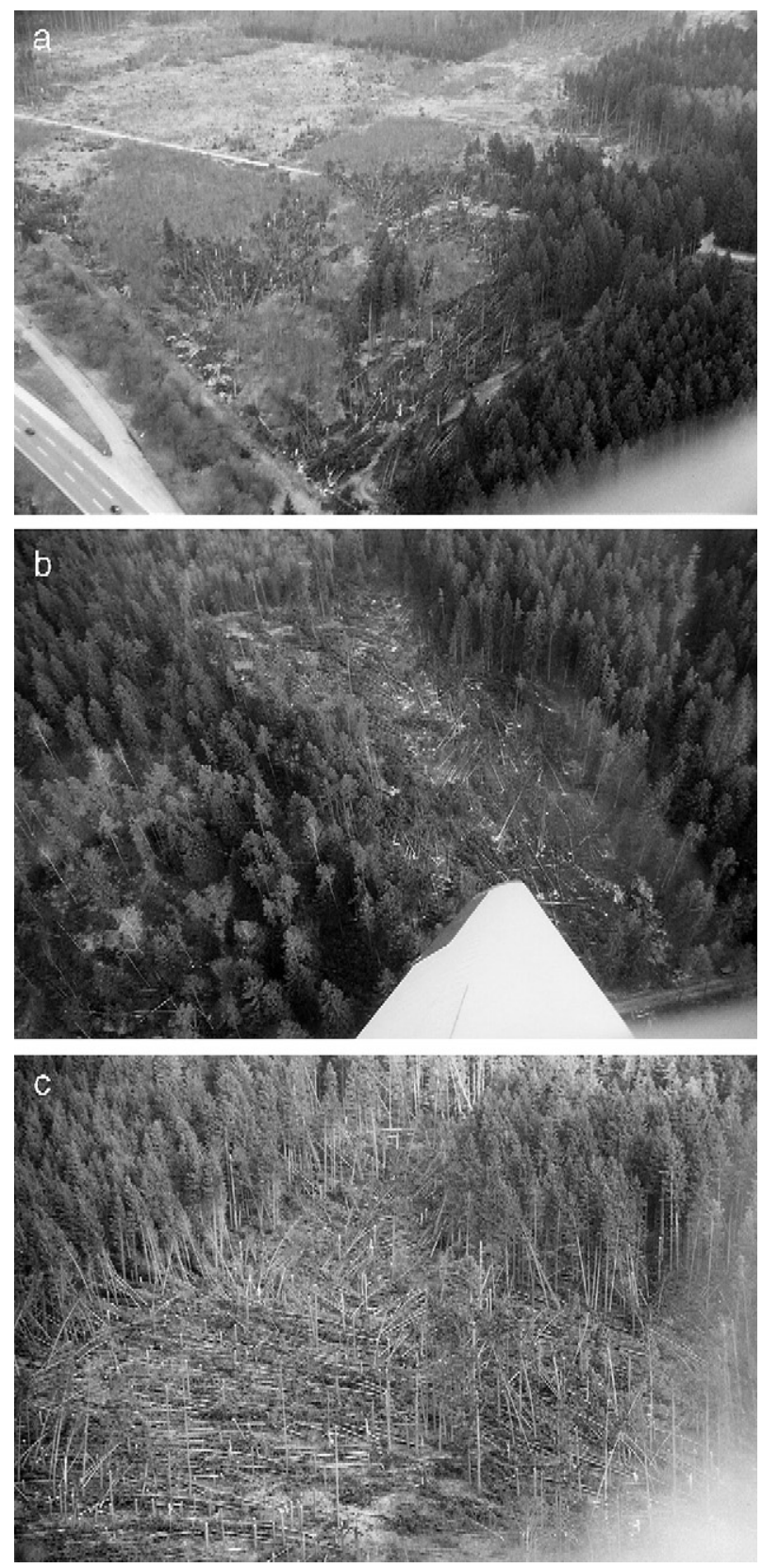

Fig. 9. Aerial views of F2 forest damage in Forstenrieder Park. Note the larger size of and consequently the higher number of downed or broken spruce trees in the damage nests.

flying debris, unlike to the cases investigated by Hannesen et al. (1998, 2000).

In contrast to those early reports of a possible tornado which were readily taken up by the media, our analysis presented here has shown stronger evidence that the 23 March event was a multiple downburst instead. This evidence is based on the facts that first, no really persistent mesocyclonic rotation was found in the storm.
Second, there were no elongated damage swaths showing signs of rotation in the trees' fall pattern. A downburst seems much more likely for this, also in light of the thermodynamic arguments outlined below.

If the damage can be regarded as downburstproduced, and not tornadic, the next question to clarify is if the storm was a supercell. Certainly, we are not dealing with a classic supercell here, but some 
characteristics were present, reminiscent of the conceptual supercell model (cf. Doswell, 2001): (i) The damage zones were located south of the CONRAD radar-derived cell track, and this together with Fig. 5a suggests the presence of a rear-flank downdraft occurring on the right (southern) flank of the storm. (ii) The storm's radar reflectivity signature was characterized by a V-notch. This particular shape is frequently reported from severe thunderstorms, and especially from supercells (cf. Dotzek et al., 2005). (iii) The location of most CG lightning strikes north of the CONRAD cell track in combination with the pronounced cyclonic wind shear on 23 March also points to a forward-sheared storm updraft and anvil region from which the CG flashes must have originated. Tilted updrafts in a strongly sheared environment are also typical of supercells. However, the main missing important characteristic of supercells is the presence of a deep, persistent mesocyclone in the storm. Hence, the downburstproducing storm on 23 March is probably best characterized as an unseasonably strong single cell storm, embedded in a fast-moving squall line which helped to prevent the typical early decay of single cell storms by keeping the updraft region slightly ahead of the line's rear flank downdraft region cold pool.

As it became obvious from this case, the bulk quantity CAPE and its related storm forecast parameters failed to indicate the potential for severe weather in advance. While the $\theta_{\mathrm{e}}$ lapse rates gave a much better indication of potential instability, many forecasters will still mainly rely on the bulk approach. To improve performance of the bulk indices in "no-CAPE" situations, it may be advisable to recompute the CAPEdependent quantities like the bulk Richardson number $R i_{\text {b }}$, etc. with some small residual amount of CAPE, say $100 \mathrm{~J} \mathrm{~kg}^{-1}$. Doing so, e.g., the resulting $R i_{\mathrm{b}}$ could still display the effects of the strong wind shear present on 23 March 2001, instead of being forced to an insignificant zero due to the zero-CAPE.

When trying to find processes likely responsible for downburst formation in this case, we have to stress that the dry air above about $500 \mathrm{hPa}$ in the presence of nearly moist adiabatic lapse rates is unusual. However, when mixing air down from above $500 \mathrm{hPa}$, there is not a lot of negative buoyancy produced. Nevertheless, it may suffice to produce entraining plume downdrafts (developing downward by evaporation of precipitation) in a wet microburst mode that could become moderately strong. Given the fast movement of the line coupled with even a moderate downburst, damaging winds seem quite plausible in this environment.
Offering a different process for downburst formation, Atlas et al. (2004) recently published the hypothesis that melting of small hailstones inside the cloud is an important trigger mechanism for downburst initiation, and only less so evaporation of rain or hydrometeor drag by large hailstones. For the melting mechanism to be most effective in triggering the downdraft, it should occur in a nearly saturated environment. Here, evaporation is inefficient, and all heat transfer from the air to the hydrometeors must go into melting the hailstones. Smaller hailstones below $1 \mathrm{~cm}$ size can occur in greater number density than large hailstones and hence expose a much larger ice surface to the surrounding air for a given hail mass content. This is analogous to the arguments presented by Kamburova and Ludlam (1966) for rain.

We find some evidence for this process in our case as well. First, no large hail was reported at the ground, yet the station Hohenbrunn reported hail up to medium intensity, i.e. number density. Due to the high radar reflectivity (above $55 \mathrm{dBZ}$ ) inside the storm, hail must have been continuously present in it, and a hail warning was diagnosed by the CONRAD software accordingly from 1430 to 1530 UTC (cf. Fig. 6a). So there would have been enough time for the Atlas et al. (2004) process to build up. The effectiveness of this melting process can be judged from the Munich soundings at 1200 UTC and 24 March, 0000 UTC (Fig. 3b,c). These reveal that the melting layer region is indeed nearly or completely saturated and, at 1200 UTC, this saturated zone extends downward from the $0{ }^{\circ} \mathrm{C}$ layer for some hundreds of meters. Therefore, the melting process is a very good candidate for downburst initiation. Thereafter, thermal stratification further below determines how intense such downdrafts can become. In the ideal case (cf. Doswell, 2001; Dotzek and Friedrich, 2003, submitted for publication), the boundary layer should have steep lapse rates and relative humidity decreasing downward. In Fig. 3b, no steep lapse rates are present, but a decrease in moisture towards the ground. So we can expect some, but weak intensification of the falling air mass. Yet as stated above, even a weak F0 downburst was sufficient on this day to cause F1 and F2 damage by superposition of the downburst horizontal flow at the surface and advection of the high horizontal momentum of storm motion from its originating levels aloft. From the soundings in Fig. 3b,c, we see that ambient wind and observed storm motion coincide at roughly the $550 \mathrm{hPa}$ level (ca. $5 \mathrm{~km} \mathrm{ASL}$ ), corresponding to mid-troposphere on 23 March.

For completeness, we mention that the Munich soundings have undergone a change in the atmospheric 
boundary layer from 1200 UTC to 24 March, 0000 UTC that may have more general implications: Passage of the downburst-producing storms has led to steeper lapse rates below $800 \mathrm{hPa}$ and the sounding now resembles a more textbook-like triangular shape of the area between the temperature and dew point profiles there. Such a low-level transition to a sounding more susceptible to downbursts by the action of downburst-producing thunderstorms themselves - was also seen by Dotzek and Friedrich (2003, submitted for publication) in their analysis of June and July 2002 downbursts in the same area.

\section{Conclusions}

Our study on two climatologically untypical downburst events originating from a fast-moving single cell thunderstorm embedded in a squall line showed the following:

- Severe thunderstorms can form and exist in an apparent "no-CAPE" environment, provided the necessary two other ingredients are there: low-level moisture and mesoscale ascent, especially in combination with synoptically forced high cell propagation speeds for which even weak F0 downbursts can cause F1 or even F2 damage.

- In "no-CAPE" situations, many severe convective storm parameters are not meaningful and should probably be recomputed with some small residual amount of CAPE to retain at least some information on interaction of instability and the wind profile.

- Very rapid storm motion was controlled by the midtropospheric flow on 23 March and together with only weak downbursts developing presented a challenge for Doppler radar nowcasting and warning.

- Apart from evaporation in entrained dry mid-level air, melting of small hail is the most probable candidate for downburst initiation. Further downburst intensification in the boundary layer was unlikely to be significant.

- Use of aerial surveys by aircraft, or in the future by meter-resolution multispectral satellite imagery, in severe convective storm post-analysis is highly recommended.

A study of downbursts in the same area in the climatologic high season in 2002 is given by Dotzek and Friedrich (2003, submitted for publication).

\section{Acknowledgements}

We are grateful for stimulating discussions with Chuck Doswell on this case. This work was partly funded by the
German Ministry for Education and Research (BMBF) under contract 07ATF45 in the project VERTIKATOR (Vertikaler Austausch und Orographie, vertical transport and orography) within the atmospheric research program AFO 2000. Stephan Thern of Siemens AG kindly provided the BLIDS lightning data. Soundings were retrieved from University of Wyoming (weather.uwyo. edu/upperair/europe.html). The TorDACH data are available at tordach.org and forest damage information was provided by Forstamt München.

\section{References}

Atlas, D., Ulbrich, C.W., Williams, C.R., 2004. Physical origin of a wet microburst: observations and theory. J. Atmos. Sci. 61, 1186-1196.

Brooks, H.E., Doswell, C.A., Cooper, J., 1994. On the environments of tornadic and nontornadic mesocyclones. Weather Forecast. 9 (4), 606-618.

Brooks, H.E., Lee, J.W., Craven, J.P., 2003. The spatial distribution of severe thunderstorm and tornado environments from global reanalysis data. Atmos. Res. 67-68, 73-94.

Cotton, W.R., Anthes, R.A., 1989. Storm and Cloud Dynamics. Int Geophys. Ser., vol. 44. Academic Press, San Diego. 883 pp.

Cummins, K.L., Murphy, M.J., Bardo, E.A., Hiscox, W.L., Pyle, R.B., 1998. A combined TOA/MDF technology upgrade of the U.S. National Lightning Detection Network. J. Geophys. Res. 103D, 9035-9044.

Dessens, J., Blin, P., 1988. Coups de vent de grain et trombes: Étude comparative sur deux cas récents (Downbursts and tornadoes: comparative study of two recent cases). Météorologie 7, 4-18 (in French).

Doswell, C.A., 1993. Extreme convective windstorms: current understanding and research. In: Proc., Spain-U.S. Joint Workshop on Natural Hazards. Barcelona, 8-11 June 1993. 11 pp.

Doswell, C.A. (Ed.), 2001. Severe Convective Storms. Meteorol. Monogr., vol. 28 (50). 561 pp.

Doswell, C.A., Brooks, H.E., Maddox, R.A., 1996. Flash flood forecasting: an ingredients-based methodology. Weather Forecast. 11, 560-580.

Dotzek, N., 2001. Tornadoes in Germany. Atmos. Res. 56, 233-251.

Dotzek, N., 2003. An updated estimate of tornado occurrence in Europe. Atmos. Res. 67-68, 153-161.

Dotzek, N., Friedrich, K., 2003. Analysis of downburst-producing storms during the VERTIKATOR field experiment in southern Germany. Preprints, 31st Conf. on Radar Meteor., Seattle, 6-12 August 2003. Amer. Meteor. Soc., Boston, pp. 78-79.

Dotzek, N., Friedrich, K., submitted for publication. Downburstproducing thunderstorms during the VERTIKATOR field experiment in southern Germany: bistatic polarimetric C-band radar analysis. Mon. Weather Rev.

Dotzek, N., Berz, G., Rauch, E., Peterson, R.E., 2000. Die Bedeutung von Johannes P. Letzmanns "Richtlinien zur Erforschung von Tromben, Tornados, Wasserhosen und Kleintromben" für die heutige Tornadoforschung (The relevance of Johannes P. Letzmann's, "Guidelines for research on tornadoes, waterspouts, and whirlwinds" for contemporary tornado research). Meteorol. Z. 9, 165-174 (in German, available at tordach.org).

Dotzek, N., Höller, H., Théry, C., Fehr, T., 2001. Lightning evolution related to radar-derived microphysics in the 21 July 1998 EULINOX supercell storm. Atmos. Res. 56, 335-354. 
Dotzek, N., Grieser, J., Brooks, H.E., 2003. Statistical modeling of tornado intensity distributions. Atmos. Res. 67-68, 163-187.

Dotzek, N., Rabin, R.M., Carey, L.D., MacGorman, D.R., McCormick, T.L., Demetriades, N.W., Murphy, M.J., Holle, R.L., 2005. Lightning activity related to satellite and radar observations of a mesoscale convective system over Texas on 7-8 April 2002. Atmos. Res. 76, 127-166.

Fehr, T., Dotzek, N., Höller, H., 2005. Comparison of lightning activity and radar-retrieved microphysical properties in EULINOX storms. Atmos. Res. 76, 167-189.

Feuerstein, B., Dotzek, N., Grieser, J., 2005. Assessing a tornado climatology from global tornado intensity distributions. J. Climate $18,585-596$.

Fujita, T.T., 1971. Proposed Characterization of Tornadoes and Hurricanes by Area and Intensity. SMRP Research Paper No. 91. University of Chicago. $42 \mathrm{pp}$.

Fujita, T.T., 1981. Tornadoes and downbursts in the context of generalized planetary scales. J. Atmos. Sci. 38, 1511-1534.

Fujita, T.T., 1985. The Downburst-Microburst and Macroburst. SMRP Research Paper No. 210. University of Chicago. 122 pp.

Fujita, T.T., Pearson, A.D., 1973. Results of FPP classification of 1971 and 1972 tornadoes. Proc. 8th Conf. on Severe Local Storms, Denver. Amer. Meteor. Soc., Boston, pp. 142-145.

Hannesen, R., Dotzek, N., Gysi, H., Beheng, K.D., 1998. Case study of a tornado in the Upper Rhine valley. Meteorol. Z., N. F. 7, 163-170 (Available at tordach.org).

Hannesen, R., Dotzek, N., Handwerker, J., 2000. Radar analysis of a tornado over hilly terrain on 23 July 2000. Phys. Chem. Earth, B 25, 1079-1084 (Available at tordach.org).

Hubrig, M., 2004. Analyse von Tornado-und Downburst-Windschäden an Bäumen (Analysis of tornado and downburst wind damage to trees). Forst Holz 59, 78-84 (In German, available at tordach.org).
Kamburova, P.L., Ludlam, F.H., 1966. Rainfall evaporation in thunderstorm down-draughts. Q. J. Royal Meteorol. Soc. 92, $510-518$.

Lang, P., 2001. Cell tracking and warning indicators derived from operational radar products. Preprints, 30th Int. Conf. on Radar Meteor., Munich, 19-24 July 2001. Amer. Meteor. Soc., Boston, pp. $245-247$.

Letzmann, J.P., 1923. Das Bewegungsfeld im Fuss einer fortschreitenden Wind-oder Wasserhose (The flow field at the base of an advancing tornado). Dissertation Thesis, Acta et Comm. Univ. Dorpat. A VI.3, 1-136 (in German, available at essl.org).

Letzmann, J.P., 1939. Richtlinien zur Erforschung von Tromben, Tornados, Wasserhosen und Kleintromben (Guidelines for research on tornadoes, waterspouts, and whirlwinds). Int. Meteor. Org., Klimatol. Komm., Protokolle der Tagung in Salzburg, 13-17 September 1937 Publ. 38, Leyden, Anlage XI, pp. 91-110 (in German, available at tordach.org).

Meaden, G.T., 1976. Tornadoes in Britain: their intensities and distribution in space and time. J. Meteorol. 1, 242-251.

Peterson, R.E., 1992a. Johannes Letzmann: a pioneer in the study of tornadoes. Weather Forecast. 7, 166-184.

Peterson, R.E., 1992b. Letzmann's and Koschmieder's “Guidelines for research on funnels, tornadoes, waterspouts and whirlwinds". Bull. Am. Meteorol. Soc. 73, 597-611.

Schroth, A.C., Chandra, M.S., Meischner, P., 1988. A C-band coherent polarimetric radar for propagation and cloud physics research. J. Atmos. Ocean. Technol. 5, 803-822.

Wegener, A., 1917. Wind-und Wasserhosen in Europa (Tornadoes in Europe). Verlag Friedrich Vieweg und Sohn, Braunschweig. 301 pp. (in German, available at essl.org). 